\title{
Premarital sex and pregnancy in Greater Jakarta
}

James O'Donnell ${ }^{1}$, Iwu Dwisetyani Utomo ${ }^{1 *}$ and Peter McDonald ${ }^{2}$

\author{
* Correspondence: iwu.utomo@anu. \\ edu.au \\ ${ }^{1}$ School of Demography, Australian \\ National University, 9 Fellows Road, \\ Acton ACT 2601, Australia \\ Full list of author information is \\ available at the end of the article
}

\begin{abstract}
Social taboos and stigmas around sexuality and non-marital sex in Indonesia have led to substantial underreporting of the prevalence of premarital sex. In this study, we explore underreporting amongst young adults in Greater Jakarta. We use the 2010 Greater Jakarta Transition to Adulthood Survey (GJTAS), a survey of more than 3000 people aged 20-34 years, to derive estimates of underreporting based on discrepancies reported in the timing of marriage, first child birth and first sexual intercourse and sexual activities. Survival and life table analyses are utilised to identify individual and societal predictors of premarital sex and its reporting and to estimate cumulative incidence across young adulthood. The results reveal substantial evidence of underreporting, particularly amongst women, arising from premarital pregnancies. We estimate that the proportion of the female cohort who will engage in premarital sex by the age of 35 years increases from 4.4 to $22 \%$ after taking into account evidence of underreporting. Premarital pregnancies and unreported premarital sex is found to be particularly common amongst lower educated people. This raises important questions for policy and research in terms of the provision of information and support for young couples and the methodological implications of substantial underreporting.
\end{abstract}

\section{Introduction}

Issues related to sexuality and reproductive health are difficult topics for research in Indonesia. Traditional and revitalised social and religious values maintain strong taboos on premarital sex and stigmatise individuals, particularly women, who participate. The resulting lack of apolitical discussion of sex within families, communities, and society means that the dominant source of education and information on sexual and reproductive health for young people comes from boyfriends, girlfriends, peers, older siblings and sexualised media content (Utomo \& McDonald, 2008; Utomo \& McDonald, 2009; Utomo, 2003). From a policy and research perspective, this makes premarital sex both a very challenging and important topic. On the one hand, females and to a lesser extent, males are likely to underreport premarital sexual activities to varying extents depending on the research context and methodologies. This leads to under-estimates of the prevalence of premarital sex and substantial discrepancies between survey instruments. On the other hand, it is an important topic given the potential personal and social

(c) The Author(s). 2020 Open Access This article is licensed under a Creative Commons Attribution 4.0 International License, which permits use, sharing, adaptation, distribution and reproduction in any medium or format, as long as you give appropriate credit to the original author(s) and the source, provide a link to the Creative Commons licence, and indicate if changes were made. The images or other third party material in this article are included in the article's Creative Commons licence, unless indicated otherwise in a credit line to the material. If material is not included in the article's Creative Commons licence and your intended use is not permitted by statutory regulation or exceeds the permitted use, you will need to obtain permission directly from the copyright holder. To view a copy of this licence, visit http://creativecommons.org/licenses/by/4.0/. 
consequences of sexually transmitted infections, unplanned pregnancies, personal and family shaming, rushed or forced marriages and unsafe abortions.

In this paper, we draw on survey data on young adults in Greater Jakarta to explore and analyse premarital sex and its reporting. In the background section, we describe the social and cultural context in Indonesia and review the challenges in measuring sexual behaviours in the international literature. This leads into our research questions and methodological approach. We then present our results and provide a discussion in which we interpret the findings and describe the study limitations. We conclude with policy implications and recommendations.

\section{Background}

\section{Premarital sex and Indonesian society}

The sexual health, awareness and development of young adults in Indonesia are buffeted by conflicting social and cultural pressures. Sex remains a taboo subject within general Indonesian society, premarital sex is forbidden and cause for deep family shame, government family planning services are legally restricted to married couples and sexual and reproductive health education is limited in schools (Situmorang, 2003; Simon \& Paxton, 2004; Utomo \& McDonald, 2009; Davies, 2014; Widyastari et al. 2015). Over many decades, these have been reinforced through traditional moderate Islamic values embodied in 'idealised morality', which in recent years have been challenged by liberal and conservative pressures.

Western and other 'modernising' influences are believed to have contributed to increasing sexual permissiveness amongst Indonesian youth. Studies throughout the 1990s and 2000s have documented growth in the sexualisation of local and imported media and associated it with increasingly liberal attitudes towards sex amongst young Indonesians (Hull, Jones, \& Sulistyaningsih, 1999; Simon \& Paxton, 2004; Jaafar, Wibowo, \& Afiatin, 2006; Nilan, 2006; Harding, 2008; Utomo \& McDonald, 2008; Utomo \& McDonald, 2009; Widyastari et al. 2015). Research suggests that most young Indonesians retain respect for the sanctity of marriage, family and the importance of, at least, female virginity (Utomo, 1997; Situmorang, 2001; Simon \& Paxton, 2004; Nilan \& Parker, 2013; BPS-Statistics Indonesia 2013). Nevertheless, young adults in Indonesia today have greater control over their lives than older generations, resulting in greater freedom to engage with the opposite sex and explore their sexuality (Wijaya, Giri, Wahyuni, \& Setiawan, 2018; Utomo \& McDonald, 2008). At least up until recently, premarital sex has been found to be increasingly acceptable amongst young people particularly in the context of a loving relationship and/or one which is expected to lead to marriage (Simon \& Paxton, 2004), or in the case of males, to gain sexual experience (Utomo, 1997; Situmorang, 2001).

This liberalisation has, in turn, been challenged by a revival of Islamic thought. Over the last two decades, different strains of this revival have sought to moderate and confront sexual permissiveness. The growth of Islamic youth groups and the emergence of an Islamic youth culture and economy, on the one hand, integrate and synthesise moderate Islamic values within modern, trendy, middle class lifestyles in which sexual piety, amongst other things, is normalised (Nilan, 2006; Utomo \& McDonald, 2008, 2009; Robinson, 2014). The parallel rise of a socially and politically conservative and 
fundamental Islamist movement, on the other hand, has exerted growing political power in seeking to aggressively push back against, and indeed reverse, liberalising sexual attitudes and behaviours (Utomo \& McDonald, 2008; Robinson, 2014). Nilan (2008) describes these as coinciding processes of 'de-traditionalisation' and 're-traditionalisation' which have competing, though often synthesised (Nilan, 2006; Nilan \& Parker, 2013), internal and external influences on personal attitudes and social norms to marriage and sexuality amongst Indonesian youth.

The Islamic revival has also diminished prospects for improved sexual and reproductive health education in schools (Utomo \& McDonald, 2008). Integrated reproductive health information is provided in primary and secondary school, which while effectiveness varies widely in quality and comprehensiveness (Utomo, McDonald, \& Hull, 2011; Utomo et al. 2012). Combined with a lack of education in the home (Utomo, 2003; Utomo \& McDonald, 2008, 2009), this creates wide diversity in the provision of knowledge and knowledge on reproductive health and sexuality to younger generations. In this light, young people are placed in a difficult position, exposed to sexualised messages from the media, youth culture and their own peer groups but without the necessary information to navigate and manage their own sexuality (Utomo, McDonald, Hull, \& Reimondos, 2010; Simon \& Paxton, 2004; Widyastari et al.'s 2015; Situmorang, 2001; Utomo, 2003). The resulting lack of sexual and reproductive health awareness has a range of potentially adverse consequences including sexually transmitted infections, unplanned pregnancies, early and forced marriages and unsafe abortions (Utomo et al. 2001; Hull, Sarwono, \& Widyantoro, 1993).

\section{Estimating the prevalence of premarital sex}

Conflicting social attitudes also create difficulties in measuring the extent of premarital sex. According to the 2012 Indonesian Demographic and Health Survey (IDHS), $8.3 \%$ of males and $1.0 \%$ of females aged 15-24 years who had never been married had experienced sexual relations (BPS-Statistics Indonesia, 2013). Comparing these results with those of the 2003 and 2007 IDHS suggests that the incidence of premarital sex may have increased from 5\% in 2003 and 6.4\% in 2007 for never married 15-24 years old males and remained constant for females (BPS-Statistics Indonesia and ORC Macro, 2003; BPS-Statistics Indonesia and Macro International, 2008). However, other smaller scale studies report substantially higher levels of premarital sexual activity (Situmorang, 2001, 2003; Purdy, 2006; Utomo \& McDonald, 2009; Widyastari et al. 2015).

Explanations for these differences relate to the sensitive nature of the topic and the methodologies used to explore them. International studies argue that survey respondents provide misleading information on sensitive topics in order to be seen to conform to socially desirable behaviours-thus creating a social desirability bias-or to avoid or manage emotional distress or threats to self-esteem (Catania, 1999). Aspects of the survey including the delivery mode, location, interviewer and the privacy and safety of the environment are thought to have a strong moderating effect on these biases (Tourangeau, Rasinski, Jobe, Smith, \& Pratt, 1997; Catania, 1999). Importantly, this implies that sexual activity can be under- or over-reported depending on both the survey and the prevailing social and cultural norms. 
A large body of international literature has addressed misreporting of sexual behaviours. Self-administered questionnaires are commonly used to reduce or eliminate bias arising from the interaction between interviewers and respondents. Pencil and paper questionnaires have been used for many years to gather information on sensitive topics (Brener, Billy, \& Grady, 2003; Dodou \& de Winter, 2014), while the use of computer assisted self-interviews (CASI) has become common more recently (Tourangeau et al,, 1997; Mensch, Hewett, \& Erulkar, 2003; Poulin, 2010; Beauclair et al., 2013; Gnambs \& Kaspar, 2015). Computer assisted self-interviews and, to a lesser extent, paper-based questionnaires often produce higher estimates of self-reported sexual activity than faceto-face interviews (Brener et al., 2003; Mullany et al., 2013; Dodou \& de Winter, 2014; Gnambs \& Kaspar, 2015). However, these effects are often small, inconsistent and context-specific (Mensch et al., 2003; Hewett et al. 2008; Potdar \& Koenig, 2005; Phillips, Gomez, Boily, \& Garnett, 2010). Further, validation of self-reports using hospital data, follow-up interviews and laboratory tests for biomarkers of sexually transmitted infections and semen suggest that sexual activity remains underreported even with these more confidential forms of data collection (Tourangeau et al., 1997; Hewett et al. 2004; Minnis et al., 2009; Kelly et al., 2014). Other techniques and variations have been trialled including in-depth interviews (Poulin, 2010), confidential voting (Gregson et al., 2004), non-verbal and random response questionnaires (Lara, Strickler, Díaz Olavarrieta, \& Ellertson, 2004; Lindstrom et al., 2010), interview location strategies (Tourangeau et al., 1997), re-interviewing or test-retest (Plummer et al., 2004; Nyitray et al., 2009; Dareng et al., 2017) and mixed methods (Plummer et al., 2004). These produce higher estimates of self-reported sexual activity than traditional face-to-face interviews though whether they produce 'true' estimates remains uncertain and doubtful.

Common to many of these studies is consistently higher reports of premarital sexual activity amongst males than females. This is argued to be the product of a widespread double standard that celebrates and stigmatises male and female sexuality respectively, leading women to suppress their sexual activity and men to exaggerate their experience. In Indonesia, part of this difference may be explained by the use of commercial sex workers amongst young men for reasons of satisfying sexual desires and increasing their sexual experiences and prowess while preserving the virginity of their girlfriends (Utomo, 1997; Situmorang, 2001; Simon \& Paxton, 2004). However, the double standard between men and women is likely to create pressures and incentives for over- and under-reporting (Simon \& Paxton, 2004; Bennett, 2005; Jennaway, 2002; Nilan, Parker, Bennett, \& Robinson, 2011). Indonesian women bear a disproportionately large share of the adverse consequences of premarital sex in the form of unplanned pregnancies, family and public shaming, forced marriages and induced abortions (Bennett, 2001; Davies, 2014). Female virginity retains disproportionately high importance amongst men and women (BPS-Statistics Indonesia, 2013). Premarital sex is often conducted in clandestine relationships, hidden from the view, most importantly, of the female's parents and family (Bennett, 2005). Thus, there are good reasons to believe women underreport sexual activity, particularly in research settings that women perceive as judgemental and/or potentially failing to protect confidentiality. Resulting underestimates of premarital sexual activity provide a false impression to society and government of the relative importance of sexual and reproductive health. 


\section{Research aims}

The present study sets out to explore the prevalence of premarital sex amongst young adults in Greater Jakarta, particularly in light of social taboos in Indonesia and the likelihood of substantial misreporting of sexual activity. We seek to answer the following research questions:

1. How does evidence of misreporting, including evidence of premarital conceptions, impact estimates of the prevalence of premarital sexual intercourse and activities amongst young adults in Greater Jakarta?

2. What factors are associated with reporting and misreporting of premarital sex and how do these shape the composition of who engages in premarital sex?

3. What is the probability that young people in Greater Jakarta will engage in premarital sexual intercourse and other activities by the end of young adulthood?

\section{Methods}

Data

The 2010 Greater Jakarta Transition to Adulthood Survey (GJTAS) collected data from more than $3000(N=3006)$ men and women aged 20-34 years in Jakarta and surrounding areas. The sampling process involved a two-stage cluster sample using the probability proportional to size (PPS) method. In the first stage, 60 Kelurahan (districts) were selected using PPS. In the second stage, five neighbourhoods (Rukun Tetangga/RT) were chosen within each selected Kelurahan by systematic random sampling. Trained interviews conducted a census in each of the 300 selected RT. The census collected information on the age, sex, marital status and relationship to the head of household. From the census, a listing of all eligible respondents (aged 20-34) living in the Rukun Tetangga was compiled. Eleven eligible persons were then selected by simple random sampling from the eligible RT population. Thus, 3300 names were selected for interview with the aim of obtaining a sample of 3000 allowing for refusals and noncontact.

The design of the GJTAS is well suited to analysis of sexual behaviours. Two standardised questionnaires were used. The first covered questions relating to demographic, social, cultural, education, work, migration, gender, health and well-being, and attitudes and values. This questionnaire was administered through face-to-face interviews with trained interviewers. The second questionnaire consisted of reproductive health and sexual behaviour questions. Survey respondents were asked whether they had ever and at what age they had first engaged in sexual intercourse. If they were married, they were asked whether they first had sex before or after marriage. Respondents were also asked whether and at what age they had first engaged in specific types of sexual activities. Sexual activities asked about were self-masturbation, masturbation with a partner, oral sex, anal sex and group sex. This was a paper-based self-administered questionnaire (SAQ) completed by respondents in private and submitted to interviewers in a sealed envelope. In cases where the respondent was not able to answer the second questionnaire due to education level or disability, the respondent was asked whether the questionnaire could be administered by an interviewer. 


\section{Measurement}

Measures of premarital sexual activity are derived from survey questions. Reported sexual intercourse is derived from a question on the SAQ asking respondents whether they had ever engaged in sexual intercourse. Respondents who responded in the affirmative and reported that they had never been married are coded as having engaged in premarital sexual intercourse. Respondents who had been married are asked whether they were married when they first engaged in sexual intercourse. If they were not married, they are also coded as having engaged in premarital sexual intercourse.

Evidence of premarital sex is also investigated by comparing dates of marriage with dates of first childbirth and sexual activity. Respondents were asked the month and year in which they were first married and the date of birth of their first child. The incidence of premarital conceptions was measured by the number of births occurring within 270 days (approximately 38.6 weeks or 9 months) of first marriage on the conservative assumption that all marriages took place on the first day of the reported month. We also produce an estimate of the number of births occurring within 244 days (34.8 weeks or 8 months) of marriage to allow for premature births and some date misreporting, and we use this estimate in the subsequent analysis.

Respondents were also asked at what age they first engaged in sexual intercourse. Respondents with evidence of a premarital conception and/or whose age at first sex was younger than their age at first marriage were coded as having engaged in premarital sexual intercourse. Respondents who said that they had never engaged in premarital sex but appear to have done so on either of these measures are said to have engaged in unreported premarital sexual intercourse. Note that, by their nature, these estimates are only available for respondents who are or have been married. Reported and unreported estimates are summed to give an estimate of total premarital sexual intercourse.

Total premarital sexual activity is estimated by adding respondents who appear to have engaged in other types of sexual activity with a partner prior to marriage. Respondents who reported that they had first engaged in sexual intercourse (reported and unreported), oral sex, masturbation with a partner, anal sex or group sex at an age younger than they were when they were first married are said to have engaged in premarital sexual activity with a partner.

\section{Analytical strategy}

Discrete-time survival models are fitted to identify predictors of premarital sex reporting and answer the third research question. These are a set of regression equations that analyse associations between the time to an event (in this case, age to first premarital sex) and a set of independent variables. The dependent variables are the log odds of engaging in premarital sexual intercourse at each age, whether (a) reported or (b) reported and unreported combined; and (c) the log odds of engaging in premarital sexual activity with a partner.

The models are run in Stata version 14 with proportional odds logistic regression (Statacorp 2015). The svy command in Stata is used to ensure the regression outputs and standard errors take account of the multi-stage sampling design of the GJTAS. The results are also weighted by sex, age group and location to ensure the results are broadly representative of young adults across the study area. The dataset is converted 
into a person-year format where each survey respondent has one row for every year they lived between age 12 and either (1) their age at first premarital sex, (2) their age at marriage where they had never engaged in premarital sex or (3) their age at the time of the survey if they had neither married nor had sex. Marriage is, in this way, treated as a competing risk-competing in the sense that once an individual marries, they can no longer be at risk of premarital sex. Separate models using the same parameters are used to predict the age of first marriage. The results are used in the construction of multiple decrement life tables described below.

A variety of specifications were tested to model how the dependent variables change over age. This included treating each single year of age and groups of ages as discrete variables (piecewise constant) and modelling smoothed log odds using polynomials and linear and cubic splines (Singer \& Willett, 1993). A third order polynomial was selected, meaning that the dependent variables are modelled as a function of respondents' age, their age squared and age cubed. This is a relatively parsimonious specification that provides results that are a good fit with the survey data. Good fit was determined by generating age and sex-specific probabilities and cumulative hazards of engaging in premarital sex from the regression models and comparing them against those produced from raw survey data.

The independent variables are sex, age group, highest completed education level, religion, self-reported religiosity, gender attitudes, how frequently respondents watch western TV and/or listen to pop music, ethnicity and parents' education. These are shown in Table 1. Education, gender attitudes, western/pop media are designed to approximate some of the important modernising influences in Indonesia, while religion, religiosity, and ethnicity are intended to reflect some of the influences of traditional values and practices. Gender attitudes are approximated through a question on the survey that asks respondents for their degree of agreement with the statement, 'Males and females should be equally represented in government and the economy'. How frequently respondents watch western TV and/or listen to pop music is a composite variable from two survey questions, the first asking respondents how frequently they watch western TV and the second how frequently they listen to pop music (Cronbach's alpha $=0.31$ ). Both items are measured on a 5-point scale-1 (every day); 2 (several days per week); 3 (once per week); 4 (less than once per week); and 5 (never). The average response to the two questions was calculated to create a 4-point scale. A proxy for ethnicity was derived from a survey question asking for the ethnic group of respondents' fathers. The most common group is Javanese with 39\% of respondents (Greater Jakarta is situated on the island of Java), followed by Sundanese people (21\%) who are native to the western part of Java and Betawi (20\%) who are also native to Jakarta. A recent demographic of ethnicity in Indonesia is given by Ananta et al. (2015).

Importantly, these variables were measured at the time of the survey where first marriage or sex occurred in the years prior to the survey. Thus, the results do not imply a causal relationship between the covariates and the act of engaging in premarital sex-particularly as variables such as highest education, religiosity and media consumption are likely to vary over the life course of young adults. Rather, this analysis is designed to identify some of the factors associated with reporting and misreporting of premarital sex. 
Table 1 Associates with reporting of premarital sexual intercourse and activity

\begin{tabular}{|c|c|c|}
\hline Variable & Categories & $\%$ respondents \\
\hline \multirow[t]{2}{*}{ Sex } & Male & 41 \\
\hline & Female & 59 \\
\hline \multirow[t]{3}{*}{ Age group } & 20-24 years & 33 \\
\hline & $25-29$ years & 32 \\
\hline & 30-34 years & 35 \\
\hline \multirow[t]{4}{*}{ Highest education level } & Up to Junior high school & 31 \\
\hline & Senior high school & 49 \\
\hline & Associate degree/diploma & 9 \\
\hline & Bachelor degree or higher & 12 \\
\hline \multirow[t]{2}{*}{ Religion } & Islam & 90 \\
\hline & Other & 10 \\
\hline \multirow[t]{4}{*}{ Religiosity } & Not religious & 12 \\
\hline & Somewhat religious & 66 \\
\hline & Religious & 15 \\
\hline & Very religious & 6 \\
\hline \multirow[t]{3}{*}{ Gender attitudes } & Agree/strongly agree & 76 \\
\hline & Not sure/not answered & 11 \\
\hline & Disagree/strongly disagree & 13 \\
\hline \multirow[t]{3}{*}{ Watch western TV and/or listen to pop music } & Never & 17 \\
\hline & Up to once a week & 48 \\
\hline & Several times a week & 35 \\
\hline \multirow[t]{4}{*}{ Father's ethnicity } & Java & 39 \\
\hline & Sunda & 21 \\
\hline & Betawi & 20 \\
\hline & Other & 12 \\
\hline \multirow[t]{4}{*}{ Parents' education } & Father did not complete high school & 57 \\
\hline & Only father completed high school & 17 \\
\hline & Mother and father completed high school & 23 \\
\hline & Unsure/do not know & 4 \\
\hline
\end{tabular}

Source: The 2010 Greater Jakarta Transition to Adulthood Survey

\section{Prediction and adjusting for censoring}

Demographic life table analysis predicts the timing and prevalence of premarital sex amongst the respondent group. This is important for treating the effects of censoring and the age composition of the survey sample and for creating a consistent basis for the comparison of estimates between subsamples and surveys (Rosero-Bixby, 1991; Cleland, Boerma, Carael, \& Weir, 2004; Zaba, Pisani, Slaymaker, \& Ties Boerma, 2004). Multiple decrement life tables are constructed for a hypothetical birth cohort who at each single year of age face age and sex specific probabilities of first getting married or having sex before their next birthday. These probabilities are calculated by converting the log odds that are output from the regression models. In this way, the timing and prevalence of premarital sex within this hypothetical birth cohort can be said to be representative of the life course experience of the survey respondents up until young adulthood. 
To illustrate, the life table starts with birth cohorts, $l^{0}$, of 100 males and females. By the age of 18 years, the size of the cohorts has reduced to $l^{18}$ individuals who have neither married nor engaged in sex. These remaining individuals face a probability $p_{\text {sex }}^{18}$ of engaging in premarital sex and a probability $p_{\text {marry }}^{18}$ of getting married by the time of their 19th birthday. The size of these cohorts are reduced to $l^{19}$ by age 19 years after removing those who marry $\left(l^{18} \times p_{\text {marry }}^{18}\right)$ and those who have non-marital sex $\left(l^{18} \times p_{\text {sex }}^{18}\right)$ during the year. Through this approach, we can estimate the total number of people who will engage in premarital sex up until the end of young adulthood (or the time they marry) by calculating the cumulative incidence. This is the sum of all those who are predicted to engage in premarital sex between ages 12 and 35 years $\left(\sum_{\mathrm{age}=12}^{35} l^{\text {age }}\right.$ $\left.\times p_{\text {marry }}^{\text {age }}\right)$. Importantly, this accounts for the potential that some respondents who have never married nor had sex at the time of the survey will do so in future (that is, they are censored) and the fact that once an individual marries, he or she is no longer at risk of premarital sex (a competing risk).

\section{Results}

\section{Prevalence of premarital sex}

Reported premarital sex varied between males and females. In total, $10 \%$ of respondents reported having engaged in premarital sex (95\% confidence interval: [9; 11]). This proportion was $16[14 ; 18] \%$ for males and $5[5 ; 7] \%$ for females. Only a small proportion (1.7\%) of respondents did not answer the question. These respondents were removed from the denominators. Amongst never married respondents who reported having ever engaged in sexual intercourse $(n=146)$, the majority had only ever been with one sexual partner (62\%) and were not currently sexually active (62\%). Those who were active were having sex 3.7 times per month on average, $45 \%$ of whom reported having had more than one sexual partner in their lifetimes. Of those who were married, $4 \%$ reported having had more than one sexual partner.

Knowledge of safe sex was lacking amongst all respondents. Two-thirds (66\%) of all respondents who had ever had sex stated that they had either not enough or no knowledge of contraception, a figure that was high irrespective of whether respondents were married (67\%), never married (58\%) or never married and sexually active (61\%). This lack of knowledge translated into a lack of practice of safe sex, with approximately one half $(52 \%)$ of never married respondents reporting that they did not use any form of contraception at the time of their first sexual intercourse. Of those never married respondents who were sexually active at the time of the survey, only $40 \%$ reported using a condom each time they had sex in the previous month.

Premarital conceptions were common amongst married respondents. Of all 1692 respondents who had ever been married, 16 [14;18]\% gave birth to a child less than 270 days after the first day of the month in which they were first married. On the more conservative measure, 14 [12; 15]\% gave birth within 244 days of marriage. Using the conservative estimate, the large majority (78\%) of premarital conceptions occurred between the respondent ages of 18 and 25 years with a modal age of 18 years. This compares with a modal age of 22 years for post-marital conceptions. Amongst those with a premarital conception, $61 \%$ were married within 6 months and $80 \%$ within 12 months. 
Despite providing evidence of premarital conception, the large majority (83\%) denied ever having engaged in premarital sex.

Further evidence of premarital sex underreporting is apparent from the ages at which respondents first engaged in sexual intercourse. Of 1543 respondents who reported they were married at the time of their first intercourse or did not give a response, $12 \%$ gave an age at which they first had intercourse that was younger than the age at which they were first married. If all respondents with evidence of unreported premarital sexon the bases of having a premarital pregnancy or an age at first sex younger than age at marriage-are reclassified as having engaged in premarital sex, the estimated proportion to have done so increases from 10 to 23\% [21; 24]. Table 2 shows the estimated prevalence of reported and unreported premarital sex by age, sex and marital status. Estimates of unreported premarital sex are highest for older and particularly female respondents. The estimated proportion of ever married female respondents aged 30-34 years old who have engaged in premarital sex, for example, increases from 4 to $30 \%$ after including the estimate of underreporting.

Other types of sexual activities were also relatively common amongst respondents. Table 3 shows the proportions of ever and never married male and female respondents who reported having engaged in masturbation with a partner or oral sex prior to marriage. Respondents were also asked whether they had engaged in anal or group sex; however, the number of responses was small and have been included only in the

Table 2 Proportion of respondents that reported having engaged in premarital sexual intercourse, by age, sex and marital status

\begin{tabular}{|c|c|c|c|c|c|c|}
\hline & \multicolumn{3}{|l|}{ Males (\%) } & \multicolumn{3}{|c|}{ Females (\%) } \\
\hline & Reported & Unreported & Total & Reported & Unreported & Total \\
\hline \multicolumn{7}{|l|}{ Ever married } \\
\hline \multirow[t]{2}{*}{$20-24$ years } & 22 & 20 & 42 & 7 & 19 & 26 \\
\hline & {$[13 ; 35]$} & {$[11 ; 33]$} & {$[29 ; 56]$} & {$[4 ; 12]$} & {$[14 ; 26]$} & {$[20 ; 34]$} \\
\hline \multirow[t]{2}{*}{ 25-29 years } & 13 & 16 & 29 & 7 & 20 & 27 \\
\hline & {$[9 ; 19]$} & {$[11 ; 22]$} & {$[23 ; 36]$} & {$[5 ; 10]$} & {$[17 ; 24]$} & {$[23 ; 31]$} \\
\hline \multirow[t]{2}{*}{$30-34$ years } & 18 & 24 & 42 & 4 & 29 & 33 \\
\hline & {$[14 ; 23]$} & {$[19 ; 29]$} & {$[36 ; 47]$} & {$[3 ; 6]$} & {$[26 ; 33]$} & {$[29 ; 37]$} \\
\hline \multirow[t]{2}{*}{ Total } & 17 & 21 & 37 & 6 & 24 & 30 \\
\hline & {$[14 ; 20]$} & {$[18 ; 25]$} & {$[33 ; 42]$} & {$[4 ; 7]$} & {$[22 ; 27]$} & {$[28 ; 33]$} \\
\hline \multicolumn{7}{|l|}{ Never married } \\
\hline \multirow[t]{2}{*}{$20-24$ years } & 12 & & 12 & 5 & & 5 \\
\hline & {$[10 ; 16]$} & & {$[10 ; 16]$} & {$[3 ; 8]$} & & {$[3 ; 8]$} \\
\hline \multirow[t]{2}{*}{$25-29$ years } & 16 & & 16 & 5 & & 5 \\
\hline & {$[11 ; 21]$} & & {$[11 ; 21]$} & {$[3 ; 10]$} & & {$[3 ; 10]$} \\
\hline \multirow[t]{2}{*}{$30-34$ years } & 27 & & 27 & 6 & & 6 \\
\hline & {$[19 ; 36]$} & & {$[19 ; 36]$} & {$[2 ; 16]$} & & {$[2 ; 16]$} \\
\hline \multirow[t]{2}{*}{ Total } & 15 & & 15 & 5 & & 5 \\
\hline & {$[13 ; 18]$} & & {$[13 ; 18]$} & {$[4 ; 7]$} & & {$[4 ; 7]$} \\
\hline \multirow[t]{2}{*}{ Total } & 16 & & 24 & 5 & & 22 \\
\hline & {$[14 ; 18]$} & & {$[22 ; 26]$} & {$[5 ; 7]$} & & {$[20 ; 24]$} \\
\hline
\end{tabular}

Note: $95 \%$ confidence intervals in square brackets 
Table 3 Reported premarital sexual activities by sex and marital status

\begin{tabular}{|c|c|c|c|c|c|c|}
\hline \multirow{2}{*}{$\begin{array}{l}\text { Proportion } \\
\text { (\%) }\end{array}$} & \multicolumn{2}{|c|}{ Ever married } & \multicolumn{2}{|c|}{ Never married } & \multicolumn{2}{|l|}{ Total } \\
\hline & Males & Females & Males & Females & Males & Females \\
\hline \multicolumn{7}{|c|}{ Oral sex or masturbation with a partner } \\
\hline \multicolumn{7}{|c|}{ Age group at survey } \\
\hline \multirow[t]{2}{*}{$20-24$ years } & 24 & 7 & 22 & 12 & 22 & 10 \\
\hline & {$[14 ; 38]$} & {$[4 ; 12]$} & {$[18 ; 26]$} & {$[9 ; 16]$} & {$[19 ; 26]$} & {$[8 ; 13]$} \\
\hline \multirow[t]{2}{*}{$25-29$ years } & 15 & 7 & 18 & 10 & 17 & 7 \\
\hline & {$[11 ; 22]$} & {$[5 ; 9]$} & {$[14 ; 24]$} & {$[6 ; 16]$} & {$[14 ; 21]$} & {$[6 ; 10]$} \\
\hline \multirow[t]{2}{*}{$30-34$ years } & 15 & 6 & 28 & 11 & 18 & 7 \\
\hline & {$[11 ; 20]$} & {$[4 ; 9]$} & {$[21 ; 28]$} & {$[5 ; 22]$} & {$[15 ; 23]$} & {$[5 ; 9]$} \\
\hline \multirow[t]{2}{*}{ Total } & 16 & 7 & 22 & 11 & 20 & 8 \\
\hline & {$[13 ; 19]$} & {$[5 ; 8]$} & {$[19 ; 25]$} & {$[5 ; 22]$} & {$[17 ; 22]$} & {$[7 ; 10]$} \\
\hline \multicolumn{7}{|c|}{ Any sexual activity with a partner (incl. intercourse) } \\
\hline \multicolumn{7}{|c|}{ Age group at survey } \\
\hline \multirow[t]{2}{*}{ 20-24 years } & 46 & 28 & 23 & 13 & 25 & 18 \\
\hline & {$[33 ; 60]$} & {$[22 ; 36]$} & {$[19 ; 27]$} & {$[10 ; 17]$} & {$[22 ; 30]$} & {$[15 ; 21]$} \\
\hline \multirow[t]{2}{*}{$25-29$ years } & 34 & 28 & 22 & 11 & 27 & 24 \\
\hline & {$[27 ; 41]$} & {$[24 ; 33]$} & {$[17 ; 28]$} & {$[7 ; 18]$} & {$[23 ; 32]$} & {$[21 ; 28]$} \\
\hline \multirow[t]{2}{*}{$30-34$ years } & 44 & 34 & 36 & 13 & 42 & 32 \\
\hline & {$[39 ; 50]$} & {$[30 ; 38]$} & {$[27 ; 46]$} & {$[7 ; 24]$} & {$[37 ; 47]$} & {$[29 ; 36]$} \\
\hline \multirow[t]{2}{*}{ Total } & 41 & 31 & 24 & 13 & 31 & 25 \\
\hline & {$[37 ; 45]$} & {$[29 ; 34]$} & {$[21 ; 28]$} & {$[10 ; 16]$} & {$[29 ; 34]$} & {$[23 ; 27]$} \\
\hline
\end{tabular}

Note: $95 \%$ confidence intervals in the square brackets

Source: The 2010 Greater Jakarta Transition to Adulthood Survey

estimates of total premarital sexual activity. Estimates are derived from the age at which respondents were first married and the age they reported for when they first engaged in each sexual activity. In total, $20 \%[17 ; 22]$ of males and $8 \%[7 ; 10]$ of females are estimated to have engaged in oral sex or masturbation with a partner prior to marriage. These sexual activities appear to be more common amongst never married respondents than amongst respondents who would be married by the time of the survey-a reversal on the figures for sexual intercourse (Table 1). This might reflect reporting issues or the greater exposure time to premarital sexual activities amongst the never married and/or a preference for non-intercourse sex amongst couples that do not get married. Combining these estimates with those for sexual intercourse, $31 \%[29 ; 34]$ of male and $25 \%[23 ; 27]$ of female respondents are estimated to have engaged in sexual activities with a partner prior to marriage.

\section{Validating the estimates}

These findings rest on the assumption that respondents correctly report their dates of marriage, childbirth and first sexual experiences. Age heaping is one potential indicator of misreporting where respondents round their age at first intercourse to the nearest round number. Figure 1 shows frequency distributions for the age of first sexual intercourse for respondents where their reported age was younger than their age of marriage. The peaks in age at first intercourse at 20 and 25 years is a signal of heaping and 


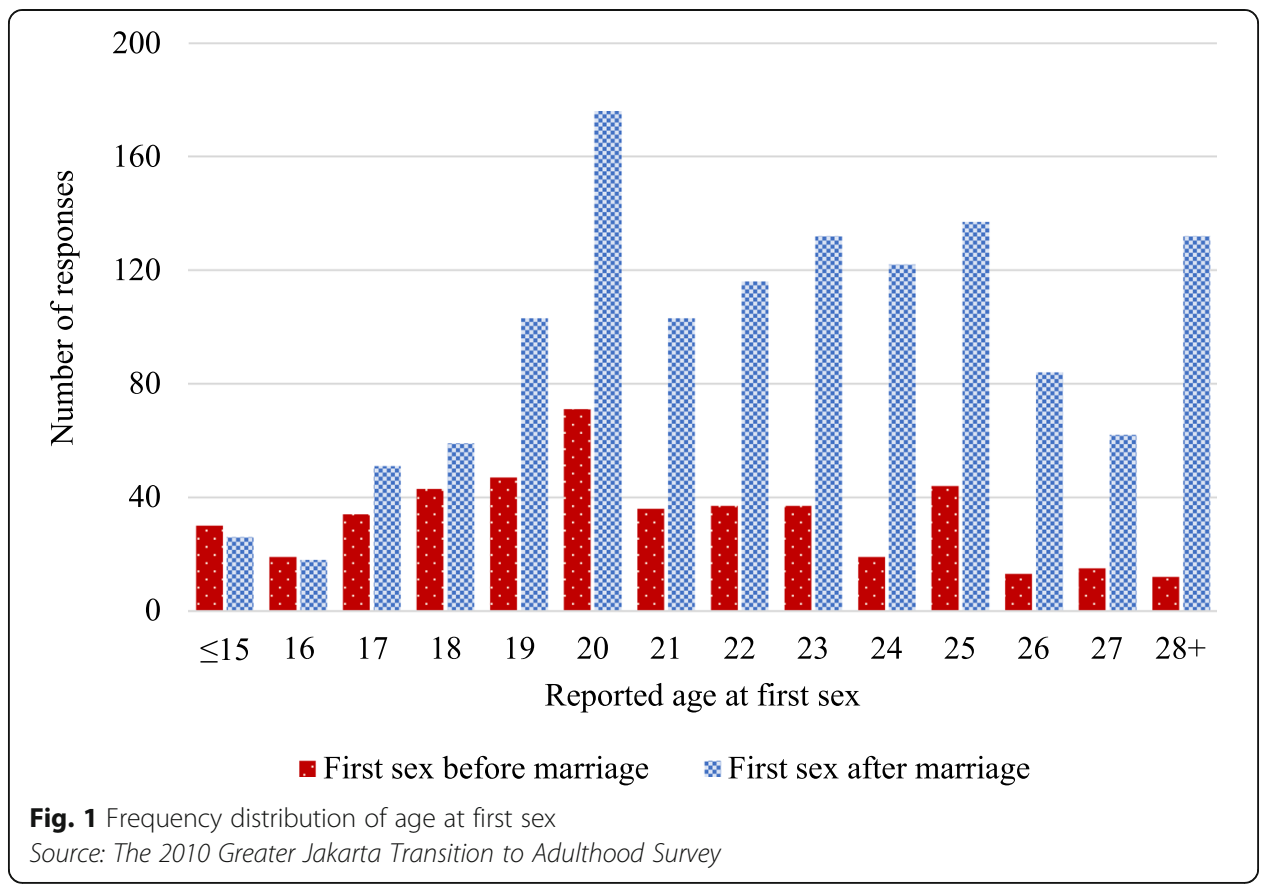

a possible indicator that estimates of unreported premarital sex are inflated by respondents rounding their age of first sexual intercourse up or down to 20 or 25 years. Graphs were also produced for reported years of marriage and first childbirth for those with evidence of premarital conceptions; however, no evidence of heaping was apparent. Intuitively, it seems plausible that respondents would have good recall of the date of their marriage and first child, but less reliable recall of the age at which they first had sex. Removing those who reported either 20 or 25 years as the age at which they first engaged in sexual intercourse, however, has little effect, leaving the proportion of respondents who gave an age of first intercourse that was younger than they were at their first marriage unchanged at $12 \%$. Thus, while there is possible evidence of age heaping, it does not appear to affect estimated underreporting of premarital sex.

Evidence for premarital conceptions are compared against results of the Indonesian Demographic and Health Survey (IDHS). This is performed by estimating the number of months between first marriage and first childbirth for ever married women and comparing these to subsamples from the 2002-2003, 2007 and 2002 IDHS editions. These subsamples are all ever married women aged 20-34 years living in the broader regions of DKI Jakarta, West Java and Banten that encompass Greater Jakarta. Importantly, the IDHS asks about the date of first cohabitation with a husband or partner rather than marriage, so the estimates are not perfectly comparable. Figure 2 presents the results, comparing the cumulative weighted proportion of married women to have given birth within $x$ months of getting married/cohabiting. The estimates are reasonably similar with $24 \%$ of the GJTAS sample giving birth within nine months of marriage, compared with 18\%,21\%, and 20\% of the population weighted IDHS 2012, 2007 and 2002-2003 subsamples respectively. The somewhat higher proportion in the GJTAS may be at least partly attributable to the difference in question wording as to the timing of marriage or cohabitation and/or to the fact that the GJTAS sample is exclusively focused on Greater Jakarta where the IDHS subsamples take in rural and other urban 


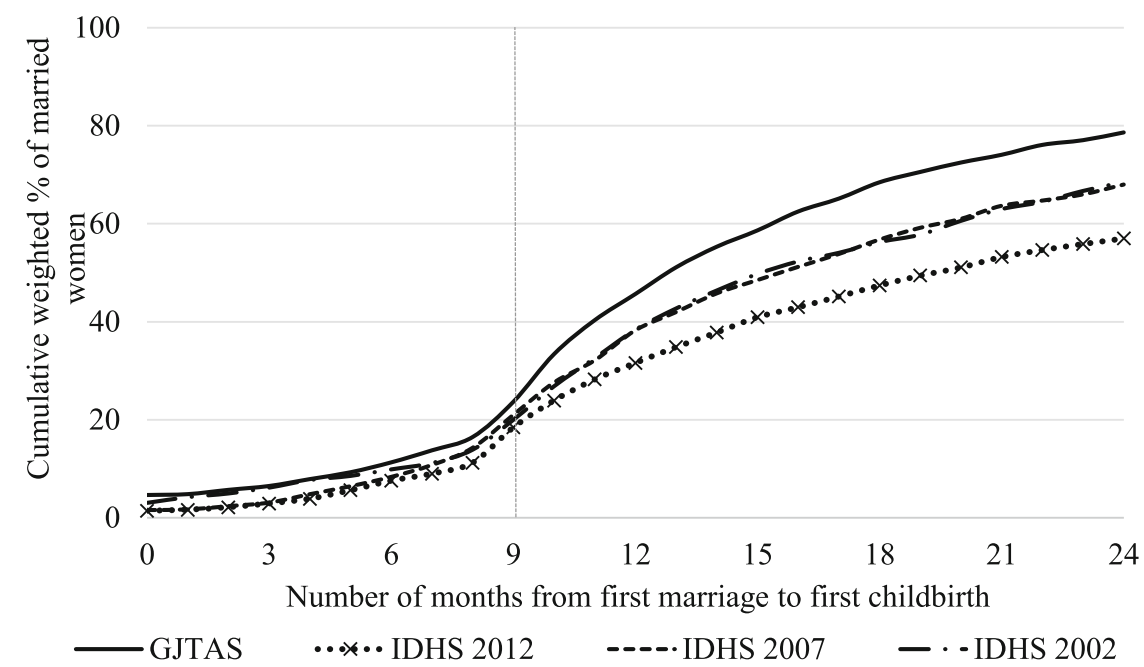

Fig. 2 Comparison of timing of marriage/cohabitation and first child birth

Source: authors' calculations from GJTAS 2010; BPS-Statistics Indonesia et al. 2013; BPS-Statistics Indonesia and Macro International 2008; BPS-Statistics Indonesia and ORC Macro 2003

populations. Nevertheless, the results are in broad agreement, providing some confidence in the GJTAS estimates.

\section{Predictors of premarital sex}

The survival analysis shows how the reporting of premarital sex varies between sociodemographic groups. Table 4 presents the results of three different models that predict the log odds of reported and total premarital sexual intercourse and total sexual activity with a partner. All the models have substantial explanatory power. The odds ratios on the age and sex variables are difficult to interpret, owing to the significance of interaction effects with age. To aid explanation, cumulative incidence functions are presented in the next section. Of the other variables, education appears to have some importance. Higher education is generally associated with lower reported and total premarital sex. The odds ratios suggest that the odds of university educated people engaging in reported sex are $53 \%$ lower than for people who have completed high school (odds ratio $=0.47[0.27,0.86]$ ). Conversely, people who have completed only up to primary school appear no more or less likely to have engaged in premarital sex based on self-reported data. However, when taking account of evidence of underreporting, primary school educated people have odds more than five times $(5.19[2.65,10.17])$ higher than those who have completed high school. The interaction between primary school education and age indicates that this effect declines with age $(0.90[0.84,0.97])$. How these effects combine to impact the cumulative incidence of premarital sex will be explored in the next section.

We find modest evidence that cultural and religious beliefs are associated with either the act or reporting of premarital sex. The odds ratios ( 0.85 and 0.78 respectively) indicate that very religious people have $15 \%$ lower odds of engaging in premarital sex on their own report than people who are somewhat religious and 22\% lower after taking account evidence of underreporting. However, the confidence intervals around these 
Table 4 Factors associated with the reporting of premarital sex

\begin{tabular}{|c|c|c|c|}
\hline & $\begin{array}{l}\text { Reported premarital } \\
\text { sexual intercourse }\end{array}$ & $\begin{array}{l}\text { Total (reported and } \\
\text { unreported) premarital sex }\end{array}$ & $\begin{array}{l}\text { Total premarital sexual } \\
\text { activity with a partner }\end{array}$ \\
\hline & \multicolumn{3}{|c|}{ Odds ratios [95\% confidence interval] } \\
\hline Age & $3.00[2.05,4.40]$ & $2.13[1.56,2.89]$ & $2.54[1.97,3.27]$ \\
\hline Age squared & $0.93[0.89,0.97]$ & $0.95[0.92,0.99]$ & $0.93[0.9,0.95]$ \\
\hline Age cubed & $1.002[1.000,1.003]$ & $1.001[0.999,1.002]$ & $1.002[1.001,1.003]$ \\
\hline \multicolumn{4}{|l|}{ Sex $[$ reference $=$ female $]$} \\
\hline Male & $4.07[1.48,11.19]$ & $0.52[0.28,0.95]$ & $1.06[0.65,1.74]$ \\
\hline Male $\times$ age & $0.97[0.87,1.08]$ & $1.05[0.99,1.12]$ & $0.99[0.94,1.05]$ \\
\hline \multicolumn{4}{|c|}{ Age cohort at time of survey [Reference $=20-24$ years] } \\
\hline $25-29$ years & $0.48[0.13,1.82]$ & $0.41[0.16,1.06]$ & $0.22[0.10,0.47]$ \\
\hline 30-34 years & $1.78[0.38,8.36]$ & $1.03[0.39,2.7]$ & $0.57[0.27,1.19]$ \\
\hline $25-29 \times$ age & $1.04[0.89,1.23]$ & $1.14[1.01,1.28]$ & $1.15[1.05,1.27]$ \\
\hline $30-34 \times$ age & $0.93[0.78,1.11]$ & $1.09[0.96,1.23]$ & $1.09[0.99,1.2]$ \\
\hline \multicolumn{4}{|c|}{ Highest education at time of survey [Reference $=$ senior high school] } \\
\hline Primary school or less & $0.90[0.22,3.65]$ & $5.19[2.65,10.17]$ & $4.65[2.58,8.37]$ \\
\hline Primary school or less $\times$ age & $1.03[0.90,1.18]$ & $0.90[0.84,0.97]$ & $0.90[0.84,0.96]$ \\
\hline Junior high school & $1.53[0.94,2.51]$ & $1.62[1.19,2.21]$ & $1.49[1.12,1.98]$ \\
\hline Academy & $0.98[0.59,1.63]$ & $0.90[0.62,1.32]$ & $0.85[0.60,1.22]$ \\
\hline University & $0.47[0.27,0.83]$ & $0.42[0.28,0.64]$ & $0.68[0.47,0.98]$ \\
\hline \multicolumn{4}{|l|}{ Religion $[$ Reference $=$ Islam] } \\
\hline Other religion & $0.90[0.54,1.50]$ & $0.91[0.61,1.34]$ & $0.80[0.57,1.13]$ \\
\hline \multicolumn{4}{|c|}{ Religiosity at time of survey [Reference $=$ somewhat religious] } \\
\hline Not religious & $1.17[0.72,1.92]$ & $1.07[0.77,1.48]$ & $1.08[0.80,1.45]$ \\
\hline Quite religious & $0.85[0.50,1.44]$ & $0.84[0.60,1.15]$ & $0.89[0.67,1.17]$ \\
\hline Very religious & $0.85[0.43,1.69]$ & $0.78[0.51,1.17]$ & $0.65[0.44,0.98]$ \\
\hline \multicolumn{4}{|c|}{ Gender attitudes [Reference $=$ agree that men and women should be equally represented] } \\
\hline Not sure/not answered & $0.81[0.39,1.69]$ & $0.88[0.58,1.36]$ & $0.94[0.65,1.36]$ \\
\hline Disagree & $0.78[0.48,1.27]$ & $1.15[0.85,1.57]$ & $1.15[0.88,1.51]$ \\
\hline \multicolumn{4}{|c|}{ Listen to western TV or pop music at time of survey [reference $=$ never] } \\
\hline Every day & $1.52[0.97,2.37]$ & $1.10[0.80,1.52]$ & $1.18[0.89,1.56]$ \\
\hline Several days a week & $1.37[0.83,2.27]$ & $1.02[0.73,1.43]$ & $1.03[0.78,1.38]$ \\
\hline Once a week & $0.59[0.31,1.13]$ & $0.61[0.43,0.87]$ & $0.69[0.50,0.96]$ \\
\hline Less than once a week & $0.67[0.38,1.19]$ & $0.80[0.58,1.09]$ & $0.88[0.65,1.19]$ \\
\hline \multicolumn{4}{|c|}{ Ethnicity of father [Reference $=$ Javanese] } \\
\hline Betawi & $2.25[1.37,3.71]$ & $1.80[1.34,2.41]$ & $1.61[1.23,2.11]$ \\
\hline Sunda & $1.45[0.90,2.33]$ & $1.38[1.02,1.87]$ & $1.38[1.05,1.81]$ \\
\hline Minang & $0.99[0.40,2.50]$ & $1.41[0.82,2.41]$ & $1.17[0.70,1.95]$ \\
\hline Hobo & $1.45[0.63,3.32]$ & $0.9[0.46,1.78]$ & $0.97[0.54,1.73]$ \\
\hline Other & $2.55[1.54,4.21]$ & $1.48[1.05,2.10]$ & $1.33[0.98,1.81]$ \\
\hline \multicolumn{4}{|c|}{ Parents level of education [Reference $=$ father did not complete high school] } \\
\hline Only father finished high school & $1.24[0.75,2.06]$ & $1.11[0.81,1.52]$ & $1.16[0.87,1.55]$ \\
\hline $\begin{array}{l}\text { Mother and father finished } \\
\text { high school }\end{array}$ & $1.61[0.98,2.65]$ & $1.22[0.87,1.71]$ & $1.24[0.92,1.68]$ \\
\hline Individuals & 2997 & 2997 & 2997 \\
\hline F statistic & $3.49(p=0.0008)$ & $4.63(p=0.0001)$ & $3.67(p=0.0006)$ \\
\hline
\end{tabular}

Source: The 2010 Greater Jakarta Transition to Adulthood Survey 
ratios, $[0.43,1.69]$ and $[0.51,1.17]$ respectively, suggest differences may be due to sampling error. Associations with TV and music are inconsistent. Compared with people who never watch western TV or listen to pop music, people who watch/listen once a week or less are less likely to have engaged in premarital sex while people who watch/ listen at least several times a week are more likely to have done so. Interestingly, the odds ratios of those who watch/listen every day falls from $1.52[0.97,2.37]$ for reported premarital sex to $1.10[0.80,1.52]$ for reported and unreported sex. While this change may be random, it may suggest that positive associations between exposure to western media and sexual behaviours are partly or wholly due to misreporting.

Family background appears to have some explanatory power. People who descend from minority ethnic groups in Greater Jakarta (non-Javanese) generally have substantially higher odds of having engaged in premarital sex. The change in odds ratios between reported and total premarital sex for people of Betawi (2.25 to 1.80), Sunda (1.45 to 1.38 ) and other (2.55 to 1.48 ) descent also suggests that Javanese people are more likely to underreport and this partly exaggerates ethnic differences. Parents' education may also have some influence, independent of a person's own education. People whose mother and father completed high school have odds $61 \%$ higher of reported premarital sex (odds ratio $=1.61[0.98,2.65]$ ) than people whose father did not complete high school, an association that declines once evidence of underreporting is taken into account (odds ratio $=1.22[0.87,1.71]$ ).

\section{Life table estimates of premarital sex}

The results of the life table analysis show the progression of premarital sex across ages. An abridged multiple decrement life table for males and females is shown in Table 5. The decrements are marriage, premarital sexual intercourse (reported and total) and premarital sexual activity with a partner. Mortality is not considered here so the results relate only to people who survive to at least 30 years. From a hypothetical birth cohort, $100 \%$ of males and $99 \%$ of females are estimated to have neither married nor engaged in premarital sexual intercourse by the age of 15 (column 4)-based on the selfreported data. Between the ages of 15 and 20 years, $4.8 \%$ of males and $1.3 \%$ of females are predicted to engage in premarital sex for the first time (column 6). Summing the predicted incidence across ages, we estimate that $18 \%$ of males and $4.4 \%$ of females will have engaged in premarital sexual intercourse by the age of 35 by their own admission (columns 7 and 8 respectively). If we include the unreported estimates of premarital sex, the 5 -year probabilities increase to the extent that $29 \%$ of all males and $22 \%$ of all females are predicted to engage in premarital sex by age 35 . If we include evidence of all sexual activities with a partner, these estimates increase to $37 \%$ of males and $25 \%$ of females. This predicted cumulative incidence of premarital sex across age is depicted in Fig. 3.

Cumulative incidence estimates can also be generated for different sociodemographic groups using the results of the survival analysis. In Fig. 4, we show the estimated marginal associations with highest education (Fig. 4a, b), exposure to western/pop media (Fig. 4c, d) and father's ethnicity (Fig. 4e, f). These are the estimated associations produced from the regression models where the values of all other covariates are held at their average values. Based on self-report data, 3.9\% of people educated up to primary 
Table 5 Abridged multiple decrement life table, marriage and premarital sexual activity by sex

\begin{tabular}{|c|c|c|c|c|c|c|c|}
\hline \multirow[b]{2}{*}{ Measure } & \multirow[b]{2}{*}{ Sex } & \multirow[b]{2}{*}{ Age } & \multirow[b]{2}{*}{ Birth cohort \% } & \multicolumn{2}{|c|}{ 5-year probability \% } & \multicolumn{2}{|c|}{ Cumulative incidence $\%$} \\
\hline & & & & Marriage & Premarital sex & Marriage & Premarital sex \\
\hline \multirow{10}{*}{$\begin{array}{l}\text { Reported premarital } \\
\text { sexual intercourse }\end{array}$} & \multirow[t]{5}{*}{ Males } & 15 & 100 & 3.7 & 4.8 & 0.3 & 0.6 \\
\hline & & 20 & 91 & 22 & 9.3 & 6.1 & 6.9 \\
\hline & & 25 & 63 & 40 & 5.4 & 30 & 15 \\
\hline & & 30 & 34 & 31 & 1.8 & 52 & 17 \\
\hline & & 35 & 23 & & & 59 & 18 \\
\hline & \multirow[t]{5}{*}{ Females } & 15 & 98 & 21 & 1.3 & 4.0 & 0.1 \\
\hline & & 20 & 76 & 47 & 2.8 & 29 & 1.3 \\
\hline & & 25 & 38 & 47 & 2.0 & 64 & 3.5 \\
\hline & & 30 & 19 & 17 & 1.1 & 76 & 4.2 \\
\hline & & 35 & 16 & & & 79 & 4.4 \\
\hline \multirow{10}{*}{$\begin{array}{l}\text { Total (reported and } \\
\text { unreported) premarital } \\
\text { sexual intercourse }\end{array}$} & \multirow[t]{5}{*}{ Males } & 15 & 99 & 3.4 & 6.1 & 0.3 & 0.9 \\
\hline & & 20 & 90 & 18 & 15 & 5.5 & 9.0 \\
\hline & & 25 & 60 & 34 & 12 & 25 & 22 \\
\hline & & 30 & 32 & 30 & 3.9 & 43 & 28 \\
\hline & & 35 & 21 & & & 50 & 29 \\
\hline & \multirow[t]{5}{*}{ Females } & 15 & 97 & 18 & 7.9 & 3.6 & 0.8 \\
\hline & & 20 & 72 & 41 & 13 & 25 & 8.5 \\
\hline & & 25 & 33 & 45 & 9.4 & 54 & 18 \\
\hline & & 30 & 15 & 19 & 2.3 & 65 & 21 \\
\hline & & 35 & 12 & & & 67 & 22 \\
\hline \multirow{10}{*}{$\begin{array}{l}\text { Total premarital sexual } \\
\text { activity with a partner }\end{array}$} & \multirow[t]{5}{*}{ Males } & 15 & 99 & 3.3 & 10 & 0.3 & 1.7 \\
\hline & & 20 & 85 & 19 & 18 & 5 & 15 \\
\hline & & 25 & 54 & 36 & 14 & 24 & 29 \\
\hline & & 30 & 27 & 31 & 10 & 42 & 35 \\
\hline & & 35 & 16 & & & 48 & 37 \\
\hline & \multirow[t]{5}{*}{ Females } & 15 & 97 & 18 & 9.3 & 3.6 & 0.8 \\
\hline & & 20 & 71 & 41 & 15 & 25 & 10 \\
\hline & & 25 & 31 & 44 & 12 & 52 & 20 \\
\hline & & 30 & 14 & 18 & 9.1 & 63 & 24 \\
\hline & & 35 & 10 & & & 65 & 25 \\
\hline
\end{tabular}

Source: The 2010 Greater Jakarta Transition to Adulthood Survey

school level are predicted to engage in premarital sex by their 35th birthday (Fig. 4a.), compared with $6.6 \%$ of University educated people (Fig. 4b.). This increases to $34 \%$ of primary school educated people and only $13 \%$ of university educated people once evidence of underreporting is included. Thus, underreporting by lower educated people appears to substantially affect and even reverse measured associations between education and premarital sex. Predicted differences are more uniform by exposure to western/pop media and ethnicity. People who watch or listen to western/pop media every day have higher expected probabilities of engaging in reported (15\%) and total premarital sex (31\%) and sexual activities (38\%) by 35 than people who never watch or listen (6.4, 22 and 27\% respectively). Likewise, people of Betawi descent have higher probabilities than Javanese people. 


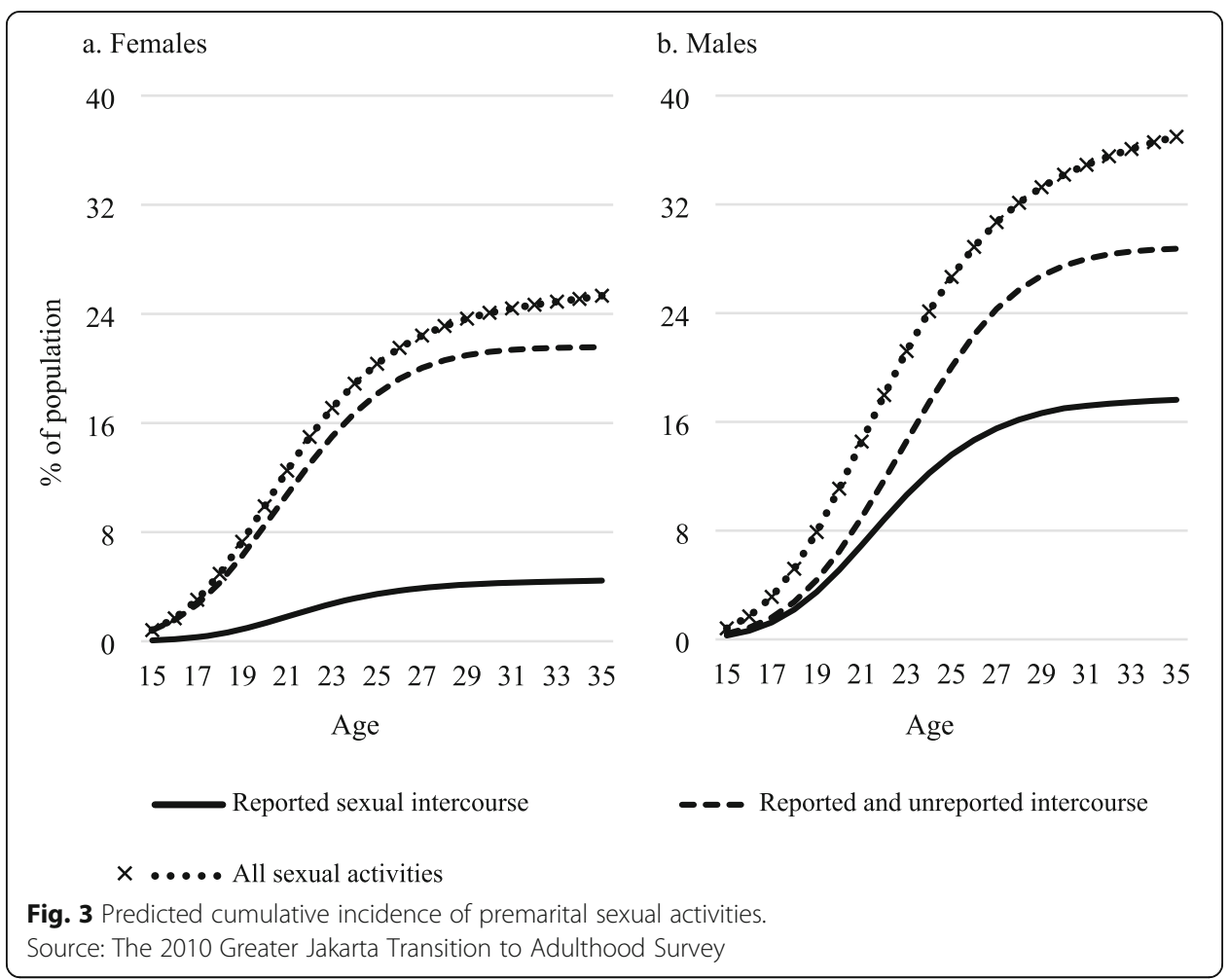

\section{Discussion}

The results of this study indicate that premarital sex is substantially more common amongst young adults in Greater Jakarta than self-reported data suggest. In this case, evidence of underreporting largely derives from evidence of premarital pregnancies. The magnitude of underreporting is large, particularly for women. Where results from the 2012 Demographic and Health Survey indicated that 1.0\% of females aged 15-24 years had engaged in premarital sex across all Indonesia (BPS-Statistics Indonesia 2013), in our study, the proportion of young women in Jakarta who are expected to engage in premarital sex by age 25 years increases from 3.5 to $18 \%$ after accounting for evidence of underreporting. By age 35, 22\% are expected to engage in premarital sex. Importantly, the effect of this underreporting is larger than the mode effects reported in much of the literature that examines whether different forms of traditional and technology-assisted survey delivery aid accuracy in reporting of sexual behaviours (Mensch et al., 2003; Hewett et al. 2008; Potdar \& Koenig, 2005; Phillips et al., 2010). Consequently, even with the best of survey designs, underreporting is likely to persist in conservative societies. The estimates of premarital pregnancies reported in this study are nevertheless plausible based on comparisons with Indonesian DHS data reported here and elsewhere (Berliana, Utami, Effendi, \& Kurniati, 2018).

We find some evidence of the conflict between traditional and modernising pressures. In one direction, ethnicity and parents' education are moderately associated with lower prevalence and/or reporting of premarital sex, while in the other direction, exposure to western media and pop music is somewhat associated with higher prevalence. Estimates of underreporting are substantially higher for females, perhaps indicative of the different standards and taboos that are applied to young men and women in their sexual 


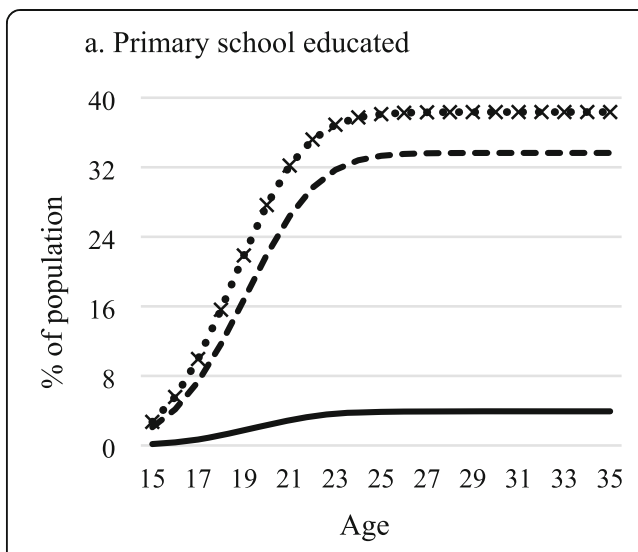

b. University educated

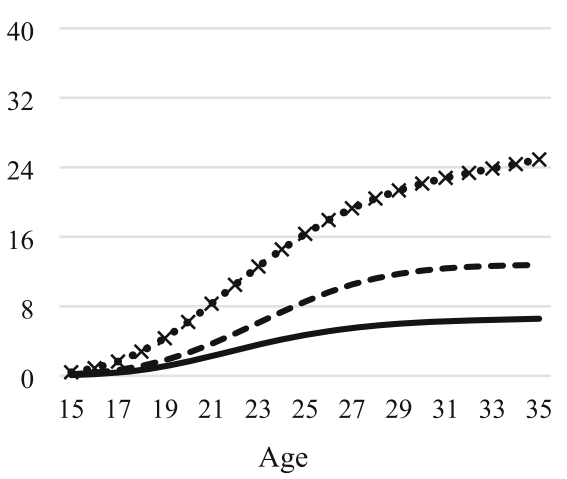

c. Never watch western TV/listen to pop

d. Watch/listen every day music
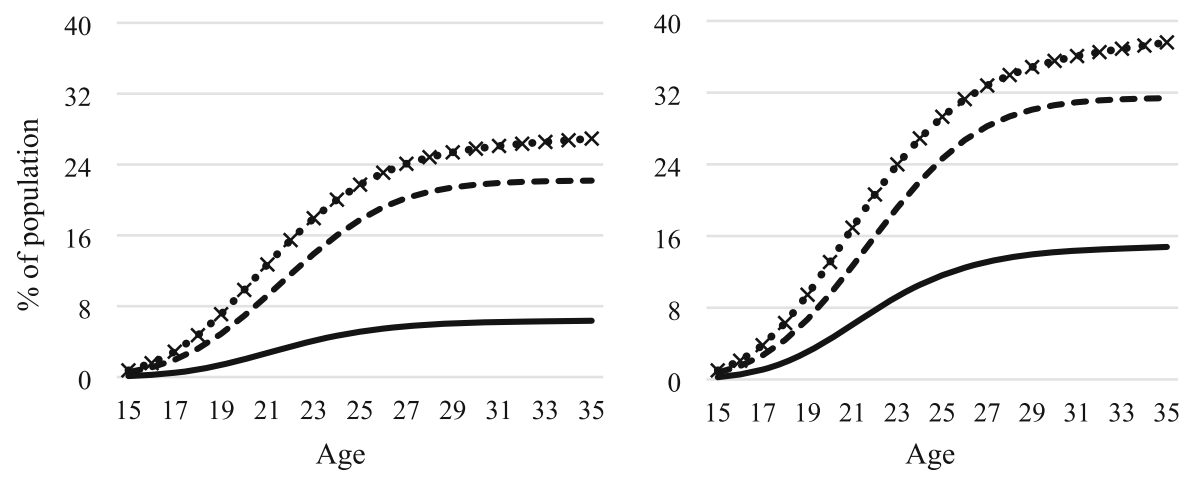

e. Javanese

f. Betawi
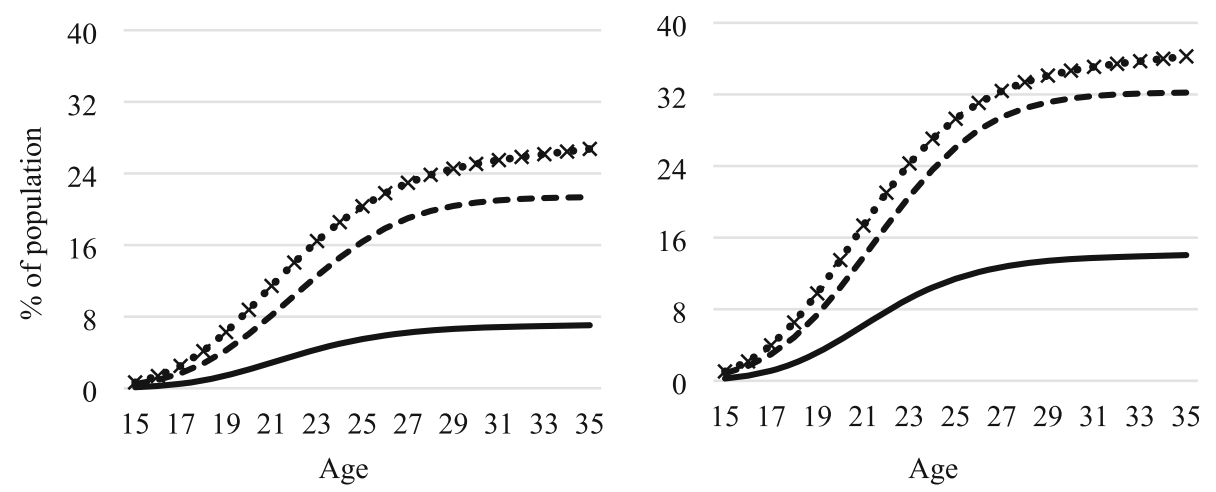

Reported sexual intercourse

- - Reported and unreported intercourse

× $\ldots$.... All sexual activities

Fig. 4 Predicted cumulative incidence of premarital sexual activities by highest education $(\mathbf{a}, \mathbf{b})$, exposure to western/pop media (c, d), and ethnicity (e, f)

Source: The 2010 Greater Jakarta Transition to Adulthood Survey

activities in Indonesian (and most other) societies (Simon \& Paxton, 2004; Bennett, 2005; Jennaway, 2002; Nilan et al., 2011). By contrast, we find weak links with religiosity and gender attitudes. Moreover, relatively strong associations with education suggest, somewhat paradoxically, that the educated class in Greater Jakarta are less likely to engage in premarital sex. There are several possible explanations for these associations, 
including that highly educated people may have better knowledge of and access to contraception, premarital pregnancies restrict later educational outcomes and that lower educated people commence their adult life course earlier and thus engage in long-term relationships that are expected to lead to marriage earlier in life. As some research suggests, these types of relationships often lead to premarital sex (e.g. Simon \& Paxton, 2004). If this is the case, external, societal-level pressures on sexual activity, including the tension between traditional and modernising factors, are likely to be at best secondary to the role of more proximal effects relating to innate desires for physical contact, intercourse and companionship and the negotiations and dynamics that occur within courtships.

Caution is warranted in the interpretation of these findings due to several limitations in the study. The retrospective nature of the data collected on sexual activities relies heavily on accurate recall, including of dates or ages at which respondents first engaged in sexual activities. Retrospectivity also precludes the estimation of causal effects, particularly as explanatory variables are determined at the time of the survey, in some cases, several years after respondents' first sexual experiences. Unreported evidence of premarital sex is largely derived from circumstantial evidence that conceptions must have occurred prior to marriage. Estimates of unreported sex thus only apply to ever married people who did not use contraception and became impregnated before marriage. Further, while they denied having engaged in premarital sex in the survey, respondents must have wittingly or unwittingly provided contradictory information in the dates and ages of marriage, first childbirth and/or first sexual activity. Thus, we do not claim to provide definitive estimates of premarital sex, but rather to show how estimates are affected by the inclusion of what evidence we have on underreporting. Finally, while Greater Jakarta is an important case and one of the most populous metropolitan centres in the world, results are not generalisable to the whole of Indonesia or other countries, particularly without coverage in rural areas and smaller urban centres.

\section{Conclusion}

Substantial evidence of premarital pregnancies reveals a complex social problem deserving of public policy attention. In the event of premarital, and probably in most cases unplanned pregnancies, marriage is likely to be an acceptable compromise for the families involved. However, it also points to a loss of independence and autonomy for young women and men at the very least in the timing of marriage and childbirth and the implications that has for education and career pathways. The potential consequences are even greater where marriage is not an option, including family shame, public ostracism, single parenthood and/or induced abortions. To the extent these are the outcomes of unplanned pregnancies, they reflect a failure of contraceptive and safe sex knowledge and practice. Such failures, of course, manifest not only in unplanned pregnancies but in a substantially heightened risk of sexually transmitted infections, a risk that many young Indonesians fail to fully understand. Provision of sexual and reproductive health services to unmarried couples, a campaign to de-stigmatise and depoliticise sexual health and a national education curriculum that includes progressive sexual and reproductive health education including safe sex messages are necessary and pragmatic solutions in this respect. 


\section{Abbreviations}

GJTAS : Greater Jakarta Transition to Adulthood Survey; SAQ: Self-administered questionnaire; RT: Rukun Tetangga/ neighbourhoods

\section{Acknowledgements}

The 2010 Greater Jakarta Transition to Adulthood Survey (GJTAS) received funding from the Australian Research Council, Ford Foundation Jakarta and the WHO. The 2014 GJTAS-Wave II was funded by the Australian Research Council and Ford Foundation Jakarta and the 2018 GJTAS-Wave III received funding from Ford Foundation Jakarta. The authors acknowledged all the funders that make this longitudinal survey possible.

\section{Authors' contributions}

IU and PM designed the study and collected the data. IU had the original idea for the paper. JO performed the analysis and wrote the first draft of the manuscript. All authors edited, proofread, and approved the manuscript for submission.

\section{Funding}

The Greater Jakarta Transition to Adulthood Survey receives funding from the Ford Foundation, the Australian Research Council, the National University of Singapore and the Australian National University.

\section{Availability of data and materials}

The datasets generated and analysed during this study are not publicly available due to the funding arrangements for this project but are available from the corresponding author on reasonable request.

\section{Competing interests}

The authors declare they have no competing interests.

\section{Author details}

${ }^{1}$ School of Demography, Australian National University, 9 Fellows Road, Acton ACT 2601, Australia. ${ }^{2}$ School of Global and Population Health, University of Melbourne, 221 Bouverie Street, Carlton VIC 3053, Australia.

Received: 16 October 2019 Accepted: 20 May 2020

Published online: 22 June 2020

References

Ananta, A., Arifin, E. N., Hasbullah, S. M., Handayani, N. B., \& Pramono, A. (2015). Demography of Indonesia's ethnicity. Singapore: Institute of Southeast Asian Studies.

Badan Pusat Statistik (BPS-Statistics Indonesia), 2013. Indonesia Demographic and Health Survey 2012: Special Report on Adolescent Reproductive Health. Preliminary report. Jakarta, Indonesia: BPS-Statistics Indonesia.

Badan Pusat Statistik (BPS-Statistics Indonesia) and Macro International. (2008). Indonesia Demographic and Health Survey 2007. Calverton, Maryland, USA: BPS-Statistics Indonesia and Macro International.

Badan Pusat Statistik (BPS-Statistics Indonesia) and ORC Macro. (2003). Indonesia Demographic and Health Survey $2002-2003$. Calverton, Maryland, USA: BPS-Statistics Indonesia and ORC Macro.

Badan Pusat Statistik (BPS-Statistics Indonesia), National Population and Family Planning Board (BKKBN), and Kemeterian Kesehatan (Kemenkes - MOH), and ICF International. (2013). Indonesia Demographic and Health Survey 2012. Jakarta, Indonesia: BPS, BKKBN, Kemenkes and ICF International.

Beauclair, R., Meng, F., Deprez, N., Temmerman, M., Welte, A., Hens, N. and Delva, W. 2013. Evaluating audio computer assisted self-interviews in urban south African communities: evidence for good suitability and reduced social desirability bias of a cross-sectional survey on sexual behaviour. BMC Medical Research Methodology, Vol 13/11: pp. 1-7.

Bennett, L.R., 2001. Single women's experiences of premarital pregnancy and induced abortion in Lombok, Eastern Indonesia. Reproductive Health Matters, Vol. 9/17: pp. 37-43.

Bennett, LR. 2005. Patterns of resistance and transgression in Eastern Indonesia: Single women practices of clandestine courtship and cohabitation. Culture Health and Sexuality, Vol. 7/2: pp. 101-112.

Berliana, S.M., Utami, E.D., Effendi, F., Kurniati, A. 2018. Premarital Sex Initiation and the Time Interval to First Marriage among Indonesians. Bulletin of Indonesia Economic Studies, Vol.54/2: pp.215-232.

Brener, N.D., Billy, J.O.G. and Grady, W. 2003. Assessment of Factors Affecting the Validity of Self-Reported Health Risk Behavior among Adolescents: Evidence from the Scientific Literature. Journal of Adolescent Health, Vol. 33/6: pp. 436-457

Catania, J.A. 1999. A Framework for Conceptualizing Reporting Bias and Its Antecedents in Interviews Assessing Human Sexuality. The Journal of Sex Research, Vol 36/1: pp. 25-38.

Cleland, J. Boerma, J.T., Carael, M. and Weir, S.S. 2004. Monitoring sexual behaviour in general populations: a synthesis of lessons of the past decade. Sexually Transmitted Infections, Vol. 80/suppl. 2: pp. ii1-7.

Dareng, E.O., Adebamowo, S.N., Eseyin, O.R., Odutola, M.K., Pharoah, P.P. and Adebamowo, C.A. 2017. Test-Retest Reliability of Self-Reported Sexual Behavior History in Urbanized Nigerian Women. Frontiers in Public Health, Vol. 5/172: pp. 1-9.

Davies, S. G. (2014). Surveilling sexuality in Indonesia. In S. G. Davies \& L. R. Bennett (Eds.), Sex and sexualities in contemporary Indonesia: sexual politics, health, diversity, and representations. Abingdon, UK: Taylor and Francis.

Dodou, D. and de Winter, J.C.F. 2014. Social desirability is the same in offline, online and paper surveys: A meta-analysis. Computers in Human Behavior, Vol. 36/2014: pp. 487-495.

Gnambs, T. and Kaspar, K. 2015. Disclosure of sensitive behaviors across self-administered survey modes: a meta-analysis. Behavior Research Methods, Vol. 47/4: pp. 1,237-1,259.

Gregson, S., Mushatu, P., White, P.J., Mlilo, M., Mundandi, C. and Nyamukapa, C. 2004. Informal confidential voting interview methods and temporal changes in reported sexual risk behaviour for HIV transmission in sub-Saharan Africa. Sexually Transmitted Infections, Vol. 80/suppl. 2: pp. ii36-42. 
Harding, C. 2008. The Influence of the 'Decadent West': Discourses of the Mass Media on Youth Sexuality in Indonesia. Intersection: Gender and Sexuality in Asia and the Pacific, Vol. 18, October.

Hull, T. H., Jones, G. W., \& Sulistyaningsih, E. (1999). Prostitution in Indonesia: its history and evolution. Jakarta, Indonesia: Pustaka Sinar Harapan.

Hull, T.H., Sarwono, S.W. and Widyantoro, N. 1993. Induced Abortion in Indonesia, Studies in Family Planning. Vol. 24/4: pp. 241-251.

Jaafar, J. Wibowo, I. and Afiatin, T., 2006. The Relationship Between Religiosity, Youth Culture, and Premarital Sex among Malaysian and Indonesian Adolescents. Asian Pacific Journal of Social Work and Development, Vol. 16/2: pp. 5-18.

Jennaway, M. (2002). Sisters and lovers: women and desire in Bali. Lanham, Maryland USA: Rowman \& Littlefield.

Kelly, C.A., Hewett, P.C., Mensch, B.S., Rankin, J.C., Nsobya, S.L., Kalibala, S. and Kakande, P.N. 2014. Using Biomarkers to Assess the Validity of Sexual Behavior Reporting across Interview Modes among Young Women in Kampala, Uganda. Studies in Family Planning, Vol. 45/1: pp. 43-58.

Lara, D., Strickler, J., Díaz Olavarrieta, C. and Ellertson, C. 2004. Measuring Induced Abortion in Mexico: A Comparison of Four Methodologies. Sociological Methods and Research, Vol. 32/4: pp. 529-558.

Lindstrom, D.P., Belachew, T., Hadley, C., Klein Hattori, M., Hogan, D. and Tessema, F. 2010. Nonmarital Sex and Condom Knowledge among Ethiopian Young People: Improved Estimates Using a Nonverbal Response Card. Studies in Family Planning, Vol. 41/4: pp. 251-262.

Mensch, B.S., Hewett, P.C. and Erulkar, A.S. 2003. The reporting of sensitive behavior by adolescents: a methodological experiment in Kenya. Demography, Vol. 40/2: pp. 247-268.

Minnis, A.M., Steiner, M.J., Gallo, M.F., Warner, L., Hobbs, M.M., van der Straten, A., Chipato, T., Macaluso, M. and Padian, N.S. 2009. Biomarker Validation of Reports of Recent Sexual Activity: Results of a Randomized Controlled Study in Zimbabwe. American Journal of Epidemiology, Vol. 170/7: pp. 918-924.

Mullany, B., Barlow, A., Neault, N., Billy, T., Hastings, R., Coho-Mescal, V., Lorenzo, S. and Walkup, J.T. 2013. Consistency in the reporting of sensitive behaviors by adolescent American Indian women: A comparison of interviewing methods. American Indian and Alaska Native Mental Health Research, Vol. 20/2: pp. $42-51$.

Nilan, P. (2006). The reflexive youth culture of devout Muslim youth in Indonesia. In P. Nilan \& C. Feixa (Eds.), Global Youth? Hybrid identities, plural worlds. Abingdon, UK: Taylor and Francis.

Nilan, P., 2008. Youth transitions to urban, middle class marriage in Indonesia: faith, family and finances. Journal of Youth Studies, Vol. 11/2: pp. 65-82

Nilan, P., \& Parker, L. (2013). Adolescents in Contemporary Indonesia. Abingdon, UK: Taylor and Francis.

Nilan, P, Parker, L., Bennett, L. and Robinson, K., 2011. Indonesian youth looking towards the future. Journal of Youth Studies, Vol. 14/6: pp. 709-728.

Nyitray, A.G., Kim, J., Hsu, C., Papenfuss, M., Villa, L., Lazcano-Ponce, E. and Giuliano, A.R. 2009. Test-Retest Reliability of a Sexual Behavior Interview for Men Residing in Brazil, Mexico, and the United States. American Journal of Epidemiology, Vol. 170/8: pp. 965-974.

Phillips, A.E., Gomez, G.B., Boily, M. and Garnett, G.P. 2010. A systematic review and meta-analysis of quantitative interviewing tools to investigate self-reported HIV and STI associated behaviours in low- and middle-income countries. International Journal of Epidemiology, Vol. 39/6: pp. 1,541-1,555.

Plummer, M.L., Ross, D.A., Wight, D., Changalucha, J. Mshana, G., Wamoyi, J., Todd, J., Anemona, A., Mosha, F.F., Obasi, A.I.N. and Hayes, R.J. 2004. "A bit more truthful": the validity of adolescent sexual behaviour data collected in rural northern Tanzania using five methods. Sexually Transmitted Infections, Vol. 80/suppl. 2: pp. ii49-56.

Potdar, R. and Koenig, M.A. 2005. Does Audio-CASI Improve Reports of Risky Behavior? Evidence from a Randomized Field Trial Among Young Urban men in India. Studies in Family Planning, Vol. 36/2: pp. 107-116.

Poulin, M. 2010. Reporting on first sexual experience: The importance of interviewer-respondent interaction. Demographic Research, Vol. 22/11: pp. 237-288.

Purdy, C.H. 2006. Fruity, Fun and Safe: Creating a Youth Condon Brand in Indonesia. Reproductive Health Matters, Vol. 14/28: pp. 127-134.

Robinson, K. (2014). Masculinity, sexuality and Islam: the gender politics of regime change in Indonesia. In S. G. Davies \& L. R. Bennett (Eds.), Sex and sexualities in contemporary Indonesia: sexual politics, health, diversity, and representations. Abingdon, UK: Taylor and Francis.

Rosero-Bixby, L. (1991). Premarital sex in Costa Rica: Incidence, trends and determinants. International Family Planning Perspectives, Vol. 17/1: pp. 25-29.

Simon, S. and Paxton, S.J., 2004. Sexual Risk Attitudes and Behaviours among Young Adult Indonesians. Culture, Health \& Sexuality, Vol. 6/5: pp. 393-409

Singer, J.D. and Willett, J.B. 1993. It's About Time: Using Discrete-Time Survival Analysis to Study Duration and the Timing of Events. Journal of Educational Statistics, Vol. 18/2: pp. 155-195

Situmorang, A., 2001. Adolescent reproductive health and premarital sex in Medan. Unpublished PhD thesis. Demography Program, Division of Demography and Sociology, Research School of Social Sciences, The Australian National University. Canberra.

Situmorang, A. (2003). Adolescent Reproductive Health in Indonesia. In A report prepared for STARH Program, John Hopkins University. Center for Communication Program: Jakarta Indonesia.

Tourangeau, R., Rasinski, K., Jobe, J.B., Smith, T.W. and Pratt, W.F. 1997. Sources of Error in a Survey on Sexual Behavior. Journal of Official Statistics, Vol. 13/4: pp. 341-365.

Utomo, B., Hakim, V., \& Habsyah, A. H. (2001). Study report incidence and social-psychological aspects of abortion in Indonesia: A community-based survey in 10 major cities and 6 districts. Depok, Indonesia: University of Indonesia Centre for Health Research.

Utomo, I.D., 1997. Sexual attitudes and behaviour of middle-class young people in Jakarta. PhD thesis, Department of Demography, Research School of Social Sciences, Australian National University: Canberra, Australia.

Utomo, I.D., 2003. Reproductive health education in Indonesia: school versus parents' roles in providing sexuality information. Review of Indonesian and Malaysian Affairs, Vol. 37/1: pp. 107-134

Utomo, I.D., McDonald, P., Hull, T., 2011. Improving Reproductive Health Education in the Indonesian National Curriculum. Paper presented at the Policy Brief Launch, BAPPENAS Jakarta. http://demography.anu.edu.au/sites/default/files/research/ gender-in-schools/Improving_RH_Policy_Brief_No_2.pdf. Accessed 16 May 2017.

Utomo, I.D., McDonald, P., Hull, T., Reimondos, A., 2010. ST//HIV Knowledge, Attitudes and Behaviour: Evidence from the 2010 Greater Jakarta Transition to Adulthood Survey. Paper presented at the First Asian Population Association Conference, 1620 November, Vigyan Bhawan, India. 
Utomo, I.D., McDonald, P., Hull, T., Reimondos, A., and Utomo, A. 2012. The Positive Impact of Reproductive Health and HIV and AIDS Education in Primary and Secondary Schools: Evidence from Jakarta, West Java, West Nusa Tenggara, and South Sulawesi. Paper presented at the Policy Brief Launch, 11 January, BAPPENAS, Jakarta. http:// http://demography.cass.anu.edu. au/sites/default/files/sod/research/gender-in-schools/Policy_Brief_\%233_Gender_RH_Knowledge.pdf. Accessed 16 May 2017.

Utomo, I.D. and Peter McDonald. 2008. Religion, Media, Westernisation and Sexuality among Young People in Urban MiddleClass Indonesia. Intersections: Gender and Sexuality in Asia and the Pacific, Vol. 18, October.

Utomo I.D. and Peter McDonald. 2009. Adolescent Reproductive Health in Indonesia: Contested Values and Policy Inaction. Studies in Family Planning, Vol. 40/2: pp. 133-146.

Widyastari, D.A., Isarabhakdi, P. and Shaluhiyah, Z., 2015. Women won't get pregnant with one sexual intercourse': misconceptions in reproductive health knowledge among Indonesian young men. Journal of Health Research, Vol. 29/1: pp. 63-69.

Wijaya, I.M.K., Giri, M.K.W., Wahyuni, N.P.D.S., Setiawan, K.H., 2018. Premarital Sex Behaviors of Teenagers: A Case in Bali, Indonesia. International Journal of Health Sciences, Vol2/3: pp. 11-12.

Zaba, B., Pisani, E., Slaymaker, E. and Ties Boerma, J., 2004. Age at first sex: understanding recent trends in African demographic surveys. Sexually Transmitted Infections, Vol. 80/suppl. 2: pp. ii28-35.

\section{Publisher's Note}

Springer Nature remains neutral with regard to jurisdictional claims in published maps and institutional affiliations.

Submit your manuscript to a SpringerOpen ${ }^{\circ}$ journal and benefit from:

- Convenient online submission

- Rigorous peer review

- Open access: articles freely available online

- High visibility within the field

- Retaining the copyright to your article 